\title{
PENERAPAN MODEL PEMBELAJARAN RECIPROCAL TEACHING TERHADAP KEMAMPUAN BERFIKIR KREATIF MATEMATIKA SISWA KELAS X SMKN
}

\author{
Ilhamsyah $^{1}$ \\ Universitas Muhammadiyah Makassar $^{1}$ \\ ilhamsyah@unismuh.ac.id ${ }^{1}$
}

\begin{abstract}
Abstrak
Penelitian ini bertujuan untuk mengetahui: (1) perbedaan rata-rata kemampuan berfikir kreatif matematis siswa yang diajar melalui Model Reciprocal Teaching dengan siswa yang diajar melalui Pembelajaran Langsung Pada Siswa Kelas X SMKN 3 Makassar pada mata pelajaran SPLTV. Jenis penelitian ini adalah penelitian quasi eksperimen semu (Quasi Experimen Desing) yang melibatkan dua kelas, satu kelas dipilih sebagai kelas eksperimen dan satu kelas sebagai kelas kontrol dengan desain penelitian Nonequivalent Control Group Desain. populasi pada penelitian ini adalah seluruh siswa kelas X SMKN 3 Makassar yang terdiri atas 2 kelas. Sampel pada penelitian ini dipilih 2 kelas secara Cluster random Sampling (area sampling) yakni kelas $X \mathrm{TKR}^{1}$ sebagai kelas eksperimen yang diberi perlakuan dengan model Reciprocal Theaching dan kelas $X T K^{2}$ yang diberi perlakuan dengan model pembelajaran langsung. Adapun instrument yang digunakan dalam penelitian ini adalah tes kemampuan berfikir kreatif matematika (posttest dan pretest). Pengumpulan data dilakukan dengan pemberian test kepada siswa diawal dan diakhir penelitian. Data yang diolah adalah data kemampuan berfikir kreatif matematika siswa dan data lembar ovservasi keterlaksanaan pembelajaran. Hasil analisis yaitu: (1) Terdapat perbedaan rata-rata kemampuan berfikir kreatif matematika siswa kelas eksperimen yang diajar dengan model pembelajaran Reciprocal Teaching dan siswa kelas kontrol yang diajar menggunakan pembelajaran langsung pada siswa kelas X SMKN 3 Makassar,(2) Kemampuan berfikir kreatif matematika siswa sebelum diterapkan model pembelajaran Reciprocal Teaching berada dalam kategori rendah dengan nilai rata-rata sebesar 62,3. Sedangkan kemampuan berfikir kreatif matematika siswa sesudah diterapkan model pembelajaran Reciprocal Teaching berada dalam kategori tinggi dengan nilai rata-rata sebesar 85.

Kata Kunci: Kemampuan, Berpikir Kreatif, Reciprocal Teaching.
\end{abstract}

\section{A. Pendahuluan}

Pendidikan adalah salah satu faktor penyebab majunya suatu Negara. Semakin bagus pendidikan suatu Negera maka semakin berkulaitas pula sumber daya manusia yang dihasilkan. Peradaban bangsa ditentukkan oleh kualitas pendidikan di suatu Negara. Negara Indonesia sangat mengedepankan pendidikan 
yang terbaik bagi bangsanya. Tujuan pendidikan diatur dalam undang-undang Sistem Pendidikan Nasional di Nomor 20 tahun 2003 pasal 3. Tujuan pendidikan nasional untuk mengembangkan kemampuan yang dimilik oleh peserta didik agar watak dan sikap terhadap PenciptaNya terjalin dengan baik dan menjadi warga Negara yang demokratis dan bertanggng jawab.

Dalam pendidikan formal, pembelajaran menunjukkan perubahan yang positif sehingga pada tahap akhir akan diperoleh keterampilan, keterampilan, dan pengetahuan baru. Hasil proses belajar tercermin dari prestasi belajarnya. Namun, dalam upaya mencapai prestasi belajar yang memuaskan, diperlukan suatu proses pembelajaran. Sultan (2004: 34) mengatakan bahwa, "belajar adalah suatu proses atau usaha yang dilakukan oleh individu untuk memperoleh suatu perubahan tingkah laku yang baru secara keseluruhan sebagai hasil dari pengalaman individu itu sendiri dalam berinteraksi dengan lingkungan”.

Guru sangat berperan aktif dalam melakukan pembelajaran agar siswa dapat belajar aktif, kreatif dan dapat memecahkan suatu masalah. Kemampuan Pemecahan masalah dapat dilakukan pada mata pelajaran matematika. Mata pelajaran Matematika dapat melatih siswa untuk belajar memecahkan masalah secara sistenatis. Menurut Cornelius dalam Mulyono (1999:253) pembelajaran matematika dapat membuat siswa untuk belajar dan berfikir secara jernih, logis, dan sarana untuk memecahkan masalah dalam kehidupan sehar-hari. Matematika merupakan mata pelajaran yang dikenal dengan mata pelajaran sulit. Kesulitan matematika berda pada tingkat yang sulit. Anggapan tersebut membuat kemmapuan berfikir secara matematis siwa sangat rendah. Hal ini disebabkan karena guru maish menggunakan metode pembelajaran yang klasik.

Berdasarkan hasil observasi yang telah dilakukan pada tanggal 19 Oktober 2018 di kelas X SMKN 3 Makassar, bahwa dalam melakukan pembelajaran guru sebagian besar menggunakan model pembelajaran langsung dan juga diperoleh informasi dari wawancara bahwa sebagian besar siswa mengalami kesulitan dalam menyelesaikan dan mengerjakan soal-soal latihan yang sedikit berbeda. dengan contoh soal yang diberikan oleh guru dan banyak siswa yang mengalami kesulitan dalam menerapkan dan memilih konsep yang benar untuk menyelesaikan masalah tersebut. 
Pembelajaran matematika yang efektif harusnya menggunakan metode pembelajaran yang representatif. Salah satu metode pembelajaran repsentatif adalah model pembelajaran terbalik (Reciprocal Teacing). Model pembelajaran terbalik adalah metode pembelajaran yang memberikan pembelajaran aktif dan mandiri. Model pembelajaran ini dapat meningkatkan keterampilan berfikir kreatif.

Kemampuan berfikir kreatif dapat meningkatkan kemmapuan siswa dalam berfikir matametis. Sehingga dapat meningkatkan minat siswa untuk belajar matematika. Berfikir krearif dapat mmebuat siswa memecahkan masalah dengan caraberfikir dan berusaha mencari solusi dalam permasalahan.

\section{B. Metode Penelitian}

Metode penelitian yang digunakan adalah penelitian eksperimen semu (Quasi Experimental Design) . jenis penelitian ini memiliki keas control tetapi tidak funsgi dari kelas control sepenunya bukan untuk mengontrol variabel-variabel. Nonequivalent Control Group Desain adalah adalah jenis penelitisan yang digunakan. Penelitian ini dilakukan dengan pretest dan posttes. lokasi penelitian dilakukan di SMKN 3 Makassar. Teknik pengumpulan data dalam penelitian ini ada dua yakni keterlaksanaan pembelajaran dan tes kemampuan berfikir kreatif matematika siswa sebelum dan setelah diterapkannya model pembelajaran Reciprocal Teaching untuk kelas eksperimen dan model pembelajaran langsung untuk kelas control. Analisis yang digunakan adalah analisis deskriptif dan inferensial.

\section{Hasil Penelitian Dan Pembahasan}

\section{Hasil Analisis Deskriptif}

Berikut ini akan diuraikan hasil analisis deskriptif yaitu kemampuan berfikir kreatif matematika siswa sebelum dan sesudah penerapan model pembelajaran Reciprocal Teaching untuk kelas eksperimen dan model pembelajaran langsung untuk kelas kontrol, keterlaksanaan pembelajaran, serta data gain. 


\section{Deskripsi Tes Kemampuan Berpikir Kreatif Matematika Siswa yang} Menggunakan Model Reciprocal Teaching Pada Siswa Kelas X TKR SMKN 3

\section{Makassar.}

Berdasarkan tes Pre-tes dan Post-tes yang diberikan pada kelas eksperimen, yang diajarkan dengan menggunakan model Reciprocal Teaching pada kelas $\mathrm{TKR}^{1}$ SMKN 3 Makassar pada materi SPLTV. Berikut ini adalah tes hasil belajar kelas ekperimen.

Tabel 1. Pre-tes Kemampuan Berpikir Kreatif Matematika Kelas Eksperimen

\begin{tabular}{ll}
\hline Statistik & Nilai \\
\hline Sampel & 25 \\
Mean & 62,3336 \\
Median & 66,6700 \\
Standard Deviasi & 15,04546 \\
Varians & 226,366 \\
Range & 50,00 \\
Nilai Minimum & 33,33 \\
Nilai Maksimum & 83,33 \\
\hline
\end{tabular}

Tabel 2. Post-tes Kemampuan Berpikir Kreatif Matematika Kelas Eksperimen

\begin{tabular}{ll}
\hline Statistik & Nilai \\
\hline Sampel & 25 \\
Mean & 85,0000 \\
Median & 83,3300 \\
Standard Deviasi & 9,62299 \\
Varians & 92,602 \\
Range & 33,33 \\
Nilai Minimum & 66,67 \\
Nilai Maksimum & 100,00 \\
\hline
\end{tabular}

Tabel 3. Statistik Frekuensi Kemampuan Berfikir Kreatif Matematika Siswa pada Kelas X TKR 1 Makassar Sebelum diterapkan Model Reciprocal Teaching

\begin{tabular}{llll}
\hline No & Interval Skor & Kualitas & Frekunsi \\
\hline 1. & $90,00-100,00$ & Sangat Tinggi & 0 \\
2. & $80,00-89,99$ & Tinggi & 3 \\
3. & $65,00-79,99$ & Sedang & 10 \\
4. & $55,00-64,99$ & Rendah & 3 \\
5 & $0,00-54,99$ & Sangat Rendah & 9 \\
\hline
\end{tabular}

Tabel 4. Statistik Frekuensi Kemampuan Berfikir Kreatif Matematika Siswa pada

Kelas X TKR 1 Makassar Setelah diterapkan Model Reciprocal Teaching

\begin{tabular}{llll}
\hline No & Interval Skor & Kualitas & Frekunsi \\
\hline 1. & $90,00-100,00$ & Sangat Tinggi & 10 \\
2. & $80,00-89,99$ & Tinggi & 7 \\
3. & $65,00-79,99$ & Sedang & 7 \\
4. & $55,00-64,99$ & Rendah & 1 \\
5 & $0,00-54,99$ & Sangat Rendah & 0 \\
\hline
\end{tabular}




\section{Deskripsi Tes Kemampuan Berpikir Kreatif Matematika Siswa yang} Menggunakan Model Pembelajaran Langsung Pada Siswa Kelas X TKR SMKN 3 Makassar.

Berdasarkan tes per-test dan pos-test yang diberikan pada kelas kontrol, yang diajakan menggunakan model pembelajaran langsung pada siswa kelas X TKR2 SMKN 3 Makassar pada materi SPLDV. Berukut ini adalah tes hasil berfikir kreatif matematika siswa pada kelas kontrol.

Tabel 5. Statistik Deskripsi Pre-tes Kelas Kontrol

\begin{tabular}{ll}
\hline Statistik & Nilai \\
\hline Sampel & 25 \\
Mean & 41,3328 \\
Median & 41,6700 \\
Standard Deviasi & 14,12517 \\
Varians & 199,520 \\
Range & 58,33 \\
Nilai Minimum & 16,67 \\
Nilai Maksimum & 75,00 \\
\hline
\end{tabular}

Tabel 6. Statistik Deskripsi Post-tes Kelas Kontrol

\begin{tabular}{ll}
\hline Statistik & Nilai \\
\hline Sampel & 25 \\
Mean & 62,3332 \\
Median & 66,6700 \\
Standard Deviasi & 14,25572 \\
Varians & 203,226 \\
Range & 50,00 \\
Nilai Minimum & 33,33 \\
Nilai Maksimum & 83,33 \\
\hline
\end{tabular}

Tabel 7. Statistik Frekuensi Kemampuan Berfikir Kreatif Matematika Siswa pada Kelas X TKR 2 Makassar Sebelum diterapkan Model Pembelajaran Langsung

\begin{tabular}{llll}
\hline No & Interval Skor & Kualitas & Frekunsi \\
\hline 1. & $90,00-100,00$ & Sangat Tinggi & 0 \\
2. & $80,00-89,99$ & Tinggi & 2 \\
3. & $65,00-79,99$ & Sedang & 11 \\
4. & $55,00-64,99$ & Rendah & 6 \\
5 & $0,00-54,99$ & Sangat Rendah & 6 \\
\hline
\end{tabular}

Tabel 8. Statistik Frekuensi Kemampuan Berfikir Kreatif Matematika Siswa pada Kelas X TKR 2 Makassar Setelah diterapkan Model Pembelajaran Langsung

\begin{tabular}{llll}
\hline No & Interval Skor & Kualitas & Frekunsi \\
\hline 1. & $90,00-100,00$ & Sangat Tinggi & 0 \\
2. & $80,00-89,99$ & Tinggi & 0 \\
3. & $65,00-79,99$ & Sedang & 1 \\
4. & $55,00-64,99$ & Rendah & 4 \\
5 & $0,00-54,99$ & Sangat Rendah & 20 \\
\hline
\end{tabular}




\section{Perbandingan Kemampuan Berfikir Kreatif Matematika Siswa Pada Kelas}

\section{Eksperimen dan Kelas Kontrol}

Perbandingan data kemampuan berfikir matematika siswa antara kelas eksperimen dan kelas kontrol dapat dilihat pada Tabel 9.

Tabel 9. Perbandingan Kemampuan Berfikir Kreatif Matematika Siswa pada kelas Eksperimen dan Kelas Kontrol

\begin{tabular}{lllll}
\hline Kelas & $\mathrm{N}$ & Mean & Std.Deviation & Std.Error Mean \\
\hline Kelas Eksperimen & 25 & 0,6191 &, 23853 &, 04771 \\
Kelas Kontrol & 25 & 0,3652 &, 14185 &, 02837 \\
\hline
\end{tabular}

\section{Deskripsi Keterlaksanaan Pembelajaran pada Penerapan Model}

\section{Pembelajaran Reciprocal Teaching dan pembelajaran langsung}

Data hasil keterlaksanaan pembelajaran selama proses penelitian yang menerapkan model pembelajaran Reciprocal Teaching pada peserta didik kelas X SMKN 3 Makassar disajikan pada tabel berikut ini:

Tabel 10. Deskripsi Hasil Persentase dan Kriteria Keterlaksanaan Pembelajaran selama Proses Pembelajaran Reciprocal Teaching

\begin{tabular}{llll}
\hline Pertemuan & Jumlah Skor & Persentase & Kriteria \\
\hline I & 66 & 75,00 & Baik \\
II & 79 & 89,77 & Baik \\
III & 83 & 94,32 & Sagat Baik \\
I-III & 228 & 86,36 & Sagat Baik \\
\hline
\end{tabular}

Tabel 11. Deskripsi Hasil Persentase dan Kriteria Keterlaksanaan Pembelajaran selama Proses Pembelajaran langsung

\begin{tabular}{llll}
\hline Pertemuan & Jumlah Skor & Persentase & Kriteria \\
\hline I & 12 & 60 & Baik \\
II & 16 & 80 & Baik \\
III & 19 & 95 & Sagat Baik \\
I-III & 47 & 78 & Sagat Baik \\
\hline
\end{tabular}

\section{Hasil Analisis Inferensial}

\section{Uji Normalitas}

Uji normalitas yang digunakan pada penelitian ini adalah uji KolmogorovSmirnova yang ada pada perangkat lunak SPSS. Hasil perhitunggan uji normalitas yang diperoleh pada peneilitian ini disajikan dalam tabel 12 berikut.

Tabel 12. Hasil Uji Normalitas Nilai N-gain Kelas Eksperimen dan Kelas Kontrol 


\begin{tabular}{lllllll}
\hline & \multicolumn{3}{l}{ Kolmogorov- } & \multicolumn{3}{c}{ Shapiro-Wilk } \\
\cline { 2 - 7 } & Smirnova & & & \\
& Statistic & df & Sig. & Statistic & Df & Sig. \\
\hline Gain Kelas Eksperimen &, 105 & 25 &, $200^{*}$ &, 940 & 25 &, 147 \\
Gain Kelas Kontrol &, 127 & 25 &, $200 *$ &, 956 & 25 &, 339 \\
\hline
\end{tabular}

\section{Uji Homogenitas}

Hasil penelitian dilakukan dengan pengolahan data secaa Homogenistas. Kriteria pengambilan keputusan adalah jika nialai sig $>a=0,05$ maka data homogen dan jika nilai sig $<a=0,05$ data tidak homogen. Uji homogenitas dapat dihitung dengan menggunakan Uji Lavene's.

Tabel 13. Hasil Uji Homogenitas Berfikir Kreatif Matematika Siswa Kelas Eksperimen dan Kelas Kontrol

\begin{tabular}{llll}
\hline Nilai Gain & & & \\
\hline Levene & df1 & df2 & df3 \\
Statistic & & & \\
8,205 & 1 & 48 &, 006 \\
\hline
\end{tabular}

\section{Uji Hipotesis}

Untuk mengetahui apakah rata-rata kemampuan berfikir kreatif matematika siswa kelas eksperimen mengalami peningkatan yang signifikan dengan rata-rata kemampuan berfikir kreatif matematika siswa kelas kontrol. Pengujian kesamaan rata-rata diolah menggunakan analisis Independent sample t-test dengan hipotesis sebagai berikut:

$$
\mathrm{H}_{0}: \mu_{1=} \mu_{2} \mathrm{H}_{1}: \mu_{1}>\mu_{2}
$$

Setelah melakukan analisis, terlihat bahwa hasil uji kesamaan dua rata-rata kelas eksperimen dan kelas kontrol menujukan nilai $\mathrm{t}=4,575$ dan sig. (2-tailed)) adalah 0,000. Nilai signifikan satu arah dari penelitian ini yaitu $0,000<0,05$. Hal ini menujukan penolakan $\mathrm{H} 0$ dan penerimaan $\mathrm{H} 1$ menyatakan bahwa rata-rata $\mathrm{N}$ gain kemampuan berfikir kreatif matematika siswa kelas eksperimen yang diajar melalui model Reciprocal Teaching lebih meningkat dari rata-rata N-gain kemampuan berfikir kreatif matematika siswa kelas kontrol yang diajar menggunakan pembelajaran langsung. 


\section{Pembahasan}

Penelitian eksperimen mengenai Recipprocal Teaching terhadap kemampuan berfikir kreatif matematika siswa kelas X SMKN 3 Makassar. Hasil penelitian ini mengungkapkan bahwa terdapat pengaruh peningkatan $\mathrm{N}$-gain terhadap kemampuan berfikir kreatif matematika siswa yang signifikan antara kelas yang diajar menggunakan model Recipprocal Teaching dan kelas kontrol yang diajar menggunakan pembelajaran langsung.

Proses pembelajaran dengan menggunakan pembelajaran model Recipprocal Teaching dan kelas kontrol yang diajar menggunakan pembelajaran langsung dilakukan selama tiga kali pertemuan dengan pertemuan terahir diadakan tes untuk mengukur kemampuan kognitif yang sama yakni 3 item soal uraian. Berdasarkan hasil penelitian yang telah diuraikan sebelumnnya maka secara deskriptif, kemampuan berfikir kreatif matematika siswa diperoleh nilai $\mathrm{N}$-gain rata-rata untuk kelas eksperimen (X TKR1) adalah 0,6191.

Berdasarkan tabel 10 dapat dilihat bahwa pada pembelajaran dapat berjalan dengan baik 75,00\% baik, pertemenuan kedua pembelajaran mengalami penigkatan menjadi 89,77\% namun masih dalam kriteria baik, hal tersebut dikarenakan terdapat dua aspek pada kegiatan inti yang diobservasi berada dalam kategori buruk. Selanjutnya pada pertemuan ketiga keterlaksanaan pembelajaran berada pada kriteria sagat baik dengan persentase yaitu 94,32\%, hal tersebut dikarenakan ada beberapa aspek kegiatan yang diobservasi terlaksana dengan sangat baik. Selanjutnya pada keterlaksanaan pembelajaran di kelas X SMKN 3 Makassar dengan penerapan model Reciprocal Teaching termasuk dalam kriteria sangat baik dengan persentase keterlaksanaan sebesar 86,36\%.Berdasarkan tabel 10 dapat dilihat bahwa pada pertemuan selanjutnya siswa berda pada kriteria baik dengan persentase $60 \%$. pembelajaran meningkat menjadi $80 \%$ namun masih dalam kriteria baik, hal tersebut dikarenakan terdapat dua aspek pada kegiatan inti yang diobservasi berada dalam kategori buruk. Selanjutnya pada pertemuan ketiga keterlaksanaan pembelajaran berada pada kriteria sagat baik dengan persentase yaitu 95\%, hal tersebut dikarenakan ada beberapa aspek kegiatan yang diobservasi terlaksana dengan sangat baik. 
Secara umum keterlaksanaan pembelajaran di kelas X SMKN 3 Makassar dengan penerapan model pembelajaran langsung termasuk dalam kriteria sangat baik dengan persentase keterlaksanaan sebesar 78\%. Materi sistem persamaan linear tiga variabel (SPLTV) (uji-t) dalam perangkat lunak SPSS, namun sebelum melakukan uji-t data penelitian harus diuji normalitas dan uji homogenitas terlebih dahulu sebagai uji prasyarat. Pengujian dilakukan dengan perhitungan menggunakan perangkat lunak SPSS 24, hasil uji normalitas diperoleh nilai signifikansi untuk Pretest $0,059>0,05$ dan Postest 0,028 > 0,05 pada kelas eksperimen dan nilai signifikansi untuk Pretest 0,320>0,05 dan Postest 0,046> 0,05 pada kelas kontrol sehingga dapat dikatakan bahwa kedua data tersebut berdistribusi normal.

Pada perhitungan uji homogenitas kelas eksperimen diperoleh nilai signifikansi 0,108 > 0,05 sehinngga dapat dikatakan bahwa kedua data tersebut homogen. Sebelum data dianalisis menggunnakan uji-t, data kemampuan berfikir kreatif siswa dikelompokkan berdasarkan kelas masing-masing yaitu kelas eksperimen dan kelas kontrol. Hal ini dilakukan guna mempermudah dalam proses analisis data. Hasil analisi t-test menujukan bahwa $t_{\text {hitung }}$ 4,575 lebih besar dari $t_{\text {tabel }}$ pada $\mathrm{df}=48$ pada taraf signifikan 0,05 yaitu sebesar 0,00 . Hal ini menujukan bahwa terdapat peningkatan rata-rata $\mathrm{N}$-gain hasil belajar matematika siswa kelas eksperimen dengan kelas kontrol. Berdasarkan pengambilan keputusan tersebut maka dapat disimpulkan bahwa ada peningkatan yang signifikan antara model pembelajaran Reciprocal Teaching dan model pembelajaran langsung terhapat kemampuan berfikir kreatif matematika siswa kelas X SMKN 3 Makassar.

\section{Kesimpulan}

Terdapat perbedaan rata-rata hasil kemampuan berfikir kreatif matematika siswa kelas eksperimen yang diajar dengan model pembelajaran Reciprocal Teaching dan siswa kelas kontrol yang diajar menggunakan pembelajaran langsung pada siswa kelas X SMKN 3 Makassar. Kemampuan berfikir kreatif matematika siswa mencapai persentase 62,3336. Sedangkan kemampuan berfikir kreatif matematika siswa sesudah diterapkan model pembelajaran Reciprocal Teaching berada dalam kategori tinggi dengan nilai rata-rata sebesar 85,0000. Kemampuan 
berfikir kreatif matematika siswa sebelum diterapkan model pembelajaran langsung berada dalam kategori sangat rendah dengan nilai rata-rata sebesar 41,3328. Sedangkan kemampuan berfikir kreatif matematika siswa sesudah diterapkan model pembelajaran langsung berada dalam kategori sedang dengan nilai rata-rata sebesar 62,3332.

\section{Daftar Pustaka}

Alfitri. (2013). Pengaruh Model Reciprocal Teaching terhadap Hasil Belajar padaMateri Persamaan Kuadrat di Kelas X SMAN 1 Ingin Jaya. Skripsi. Banda Aceh: Universitas Syiah Kuala.

Afrizon, R., Ratnawulan, R., \& Fauzi, A. (2012). Peningkatan perilaku berkarakter dan keterampilan berpikir kritis siswa Kelas IX MTsN Model Padang pada mata pelajaran IPA-fisika menggunakan model problem-based instruction. Jurnal Penelitian Pembelajaran Fisika, 1(1).

Artiah, A., \& Untarti, R. (2017). Pengaruh Model Reciprocal Teaching Terhadap Kemampuan Representasi Matematis Siswa Kelas VII SMP Negeri 6 Purwokerto. AlphaMath: Journal of Mathematics Education, 3(1).

Baharuddin, M. R. (2020). Profil Kemampuan Literasi Matematis Mahasiswa PGSD. Cokroaminoto Journal of Primary Education, 3(2), 96-104.

Firdaus, A. M. (2019). Application of cooperative learning model type Think Pair Share (TPS) on mathematical communication ability. Daya Matematis: Jurnal Inovasi Pendidikan Matematika, 7(1), 59-68.

Garderen, D. V., (2004). "Reciprocal Teaching As A Comprehension Strategy For Understanding Mathematical Word Problems". Reading And Writing Quarterly. New York: Taylor \& Francis Group.

Hardianto, H., \& Baharuddin, M. R. (2019). Efektifitas Penerapan Model Pembelajaran PAIKEM Gembrot terhadap Peningkatan Hasil Belajar Mahasiswa pada Mata Kuliah Pembelajaran Matematika Sekolah Dasar. Cokroaminoto Journal of Primary Education, 2(1), 27-33.

Permatasari I., (2017). Pengaruh pembelajaran matematika menggunakan model Reciprocal Teaching terhadap kemampuan Berfkir Kreatif Matematika siswa yayasan Madrasah Ilmiyah Medan tp 2017/2018.Universitas Islam Negri Sumatra Utara.

Marwan. (2016). Meningkatkan Kemampuan Pemahaman dan Berpikir Kritis Matematis siswa SMK melalui Model Pembelajaran Berbasis Masalah. Jurnal Didaktik Mtematika, 3(2) 
Noorliani, \& Kusumawati, E. (2013). Pengaruh Model Reciprocal Teaching Terhadap Hasil Belajar Matematika Siswa Kelas VIII SMP.

Nurhasanah, S., (2010). Pengaruh Model Reciprocal Teaching terhadap Kemampuan Berpikir Kritis Siswa dalam Belajar Matematika. Jurnal Matematika.

Ruminiati, (2012). Bahan Ajar Perkembangan PKn 1. Disajikan dalam perkuliahanyang dilaksanakan di jurusan PGSD Fakultas Keguruan dan Ilmu Pendidikan. Unismuh Makassar.

Siswono, T. Y. E., (2005). Upaya Meningkatkan Kemampuan Berpikir Kreatif Siswa Melalui Pengajuan Masalah, Jurnal Pendidikan Matematika dan sains, 1(1)

Thobroni. (2016). Belajar dan pembelajaran teori-teori \& praktek. Yogjakarta: ArRuzz Media.

Trianto, (2010), Model Pembelajaran Inovatif-Progresif, Jakarta: Kencana Prenada Media Group, hal. 173

Vahlia, I. \& Sudarman, S.W. (2015). Penerapan Model Pembelajaran Berbalik (Reciprocal Teaching) Ditinjau dari Aktivitas dan Hasil Belajar Siswa, 4(1) 